\title{
The Exploration of the University Funded Education with the Guidance of the Socialist Core Values
}

\author{
Liu Hui \\ University of Electronic Science and Technology of China, Zhongshan Institute \\ Zhongshan, 528402, China \\ E-mail:26364127@qq.com
}

\begin{abstract}
Based on the investigation of poor college students in cultivating and practicing the socialist core values, this paper proposes to build cycle paths of cultivating and practicing the socialist core values which mean from consciousness internalizing to behavior externalizing, and then to enhance idea identity. Meanwhile, we should establish and improve a safeguard mechanism to maintain the effectiveness of education, make the poor students grow healthily, consolidate and safeguard the results of the construction of the socialist core values.
\end{abstract}

Keywords-Socialist core values; Funded education; Poor College Students

\section{Introduction}

College funding education work guided by the socialist core values contains the connotation requirements of the socialist core values, which is an effective way to solve poor college students values problems, improve the system of subsidy system in colleges, and then build a harmonious society.

500 survey questionnaires were distributed and 440 effective ones were acquired. The questionnaire is divided into four parts: the personal details, the awareness of socialist core values, activities related with socialist core values organized by university as well as taken part in by poor students. From the survey results, all colleges and universities have carried out various forms education activities on socialist core values, poor students have known the meaning and the essence in a certain extent. They also through a variety of activities for public welfare in their daily life, study to be in practice, but there are some problems can not be ignored, is the need to focus on ideological and political workers and resolve at work.
II. Paths to cultivate and practice the socialist core values A. Internalization paths to cultivate the socialist core values

The internalization path to cultivate the socialist core values is a curing process of integrating the essence of the socialist core values into personal awareness progressively, through learning and thinking and other speculative activities.

"External factors are conditions of change, internal factors are the basis of change, and external factors do work through internal ones.”[1] Compared with ordinary non-poor students, on the one hand,poor students are inferior , more sensitive, stronger self-esteem, on the other hand they are more pragmatic, easier to accept love from the outside world. The way to develop their values can be divided into three stages : stage of cognitive , stage of emotional resonance , stage of awareness curing.

1. Stage of cognitive: The stage of cognitive refers to a stage in which correctly understanding the basic components of socialism core values on the basis of a systematic study of the theory. In the teaching process, teachers and students must advance with the times and use new media ways, such as WeChat, QQ, microblog, to teach and learn knowledge. Only close to students' life, can we input "boring” theoretical knowledge to the students.

2. Stage of emotional resonance: The goal of socialist core value system theory is to educate, guide and mold human, which can not be achieved relying on empty theory preaching. We must pay attention to humanistic care and education on the basis of emotion. Teachers can touch poor students' heart through inspirational models, thought and discussion on the hot social phenomenon, as well as volunteer activities, etc. Inspiring emotion with knowledge, promoting knowledge 
with feelings. Eventually we can put the socialist core values into the emotional system of poor students.

3. Stage of awareness curing: Ideological and political workers should master the rules of thinking, combine knowledge taught in class with self-study, self-thought and social practice in order to guide students to do things voluntarily in accordance with the requirements of the socialist core values. Making the intrinsic theoretical knowledge into outside good behavior, and ultimately forming habits stated by socialist core values, realizing the curing of theory in the field of ideology.

\section{B. Externalization paths to practice the socialist core values}

The externalization path to practice the socialist core values is a process to spread and promote the socialist core values through in -out school practices and behavior conformed to the standard of the socialist core values ."Education of social practice is a breach for students to identify the socialist core values." ${ }^{[2]}$.

1. Pay attention to develop the infection effect of values during school extracurricular activities

Quite a number of poor students hope to grow and change during the period of university, but they are afraid to take part in various activities because of inferiority, introverted and other psychological reasons. At this point, aid workers need to pay positive attention and promotion to the students, with the help of the infectivity of extracurricular activities and friendship between people, and then imput the socialist core values to the mind of students imperceptibly.

2. Pay attention to develop the guiding function of values during social practice activities

"Facts speak louder than words", the actual educational activities are more effective than many theory courses. It is to practice the socialist core values that from perceptual knowledge to rational knowledge, from a rational understanding to active participation, guiding practice, and that cycle repeats, then putting thoughts and actions into one.

3. Pay attention to the cultivation of values during daily behavior

We should connect daily habits of life and study with the social core values from the beginning of the university. The daily habits contains saving of electricity, a drop of water, being honest in examinations, and treating people sincerely ,etc.. We should cultivate good living habits, good style of study, healthy consumption patterns, etc in our behaviors to follow the requirements of the socialist core values

C. Security mechanism of cultivating and practicing the socialist core values

1. Advancing with the times, establishing and improving the funding policy

The majority of poor students come from remote areas or mountainous areas, with poor learning basis, weak ability, so they spend a lot of time to part-time to earn a living during the school, it is difficult to obtain high scholarship, and the yearly grant funding can not meet their needs. Therefore, the party and the government should consider the actual situation of universities, abandon the "one size fits all" type of funding model, draw on the experience of developed countries or other developing countries, and carry out a diversified, multilevel, and differentiated subsidy policy.

2. Transforming the funding model, creating a funding atmosphere, paying attention to education after aid financially.

The funded work of some colleges and universities is merely on the level of economic assistance, which is lack of deep-seated moral education, such as the education of self confidence, self-reliance, self - improvement and integrity, gratitude. To change the simple funding model of "Giving money is all”.

We should help poor students to foster correct world outlook, views on life and values, and make the construction of healthy psychological mechanism as the key work. Making efforts to create a atmosphere of self-reliance, human integrity and resist thoughts of passive, lazy and other dishonesty phenomena. Combined with its own reality, universities should set an example, do a good job of propaganda, establish a sense of integrity in order to create a healthy social environment for the growth of poor students.

3. Forming a specialized aid and education team, recording and tracking the ideological state of poor students

General Secretary $\mathrm{Xi}$ Jinping stressed during the conversation of the Thirteenth Central Committee Political Bureau collective learning that it's "a basic project of gathering the spirit and strengthening the foundation" to 
cultivate and carry forward the socialist core values. We should fully realize that the values shaping is along-term, so we need to build a specialized, professional team ,enhancing their theoretical attainment who will pay close attention to what are the poor students thinking and doing, record their daily actions, their psychology state and the changing of their mind, track their growing process. In the end, we protect their minds from decadent ideas and prevent values from being volatile and backward.

\section{CONCLUSION}

College funding education work contains connotation requirements of the socialist core values. It's the realistic demand of ideological and political education in colleges to subsidize students in the economy, help students in spirit, lead students on the values, shape students in personality by integrating the socialist core values into the funding education work to improving the effectiveness of funding. All above plays an important role in training socialist builders and successors with healthy body and mind, firm political stand.

\section{ACKNOWLEDGMENT}

This work is support by the Youth Science Fund Project of University of Electronic Science and Technology of China Zhongshan Institute 2015.(No.415YJ03), all support is gratefully acknowledged.

\section{REFERENCES}

[1] Mao Zedong.The selected works of Mao Zedong (volume first) [M]. Beijing: People's Publishing House,1991:302.

[2] Ning Xiansheng,Shi Xinyu.The socialist core value system and contemporary social thought [M]. Beijing: Social Sciences Academic Press, 2011.

[3] CPC Central Committee. Opinions on the cultivation and practice of socialist core values. People's Daily, 2013-12-24.

[4] Zhang Bo,Deng Zhuoming,ZouLi.Ideological discourse power: the challenge and path of the cultivation of College Students' socialist core values [J], ideological education research, 2015 (1) 